\title{
Use of tannin containing browse tree/ shrubs in the control of intestinal parasites (helminthes) in small ruminants: review
}

S.B. Abdu ${ }^{1 *}$, O.W. Ehoche ${ }^{2}$, A.M. Adamu, G.E. Jokthan ${ }^{1}$ M. R. Hassan ${ }^{1}$ and H.Y. Adamu ${ }^{1}$

${ }^{1}$ Department of Animal science Ahmadu Bello University, Zaria, Kaduna State, Nigeria

${ }^{2}$ National Animal Production Research Institute Shika, Zaria

*abdusb@gmail.com Tel: +2348060398664

\section{Abstract}

The overall aim of this review was to evaluate the antihelminthics activity of browse forages containing secondary plant factors. Results from literature have shown the benefits of feeding browse foliage in terms of nutrient supply, supplementation supported animal growth and performance. It was found that supplementation with browse leaf meal reduced worm fecundity, also reduces the worm burdens and total fecal egg counts during feeding period. It is concluded that browse foliage can be used to reduce the adverse effects of intestinal parasite infections in ruminant, hence reducing the need for costly antihelminthics drugs and the devel opment of resistance to these drugs.

Keywords: Antihelminthics, browse foliage, intestinal parasite, tannins

\section{Introduction}

The importance of small ruminants in the tropics in general is well recognized (Williamson and Payne, 1978). It is important to note that livestock contributes significantly to improve livelihood, through conversion of natural vegetation and crop residues into animal protein and manure. Their product is easily and quickly sold and thus serves as monetary reserve for rural farmers. They can be owned by rural households and then can have a significant contribution to income generation and food security in a large scale in developing countries.

Njoya et al. (2005) indicated that despite the important economic, traditional, social and religious role of small ruminants, their productivity is seriously hampered by high mortalities due to mixed infections by 'peste des petits ruminants' and gastro-intestinal helminthoses and also by poor feeding and management. The number of diseases in small ruminants and the lack of appropriate feeds lead to low productivity characterised by high mortality and loss of weight (Bourzat, 1980).

Parasites were considered to be a major health hazard for goats particularly in hilly and swampy regions (Battacharya, 1989). Endoparasites were also considered to be a major constraint to goat improvement (Shavulimo, 1989). Parasites in the abomasum and small intestine causes extensive protein losses in the digestive tract of sheep (Kimambo et al., 1998). The impairment of production due to parasite infection, as a result of inefficient food utilization, has been explained (Sykes, 1994; Roy et al., 2003).

The need for alternative means of parasite control is urgent, because of the serious problems associated with parasites, the availability of sub-standard anthelmintics, and sometimes also because of high levels of anthelmintic resistance (Chandrawathani et al., 2004; Hood, 2004). The control of gastro intestinal parasites is becoming more difficult due to the increased resistance of parasites to common 
anthelmintics dewormers, commonly available in the markets, has been reported in goats, sheep, and cattle (Prichard, 1994; Pomroy et al., 2002). Alternative parasite management strategies using forages containing condensed tannins have recently been suggested (Niezen et al., 1995; Barry et al., 2001; Min etal., 2002).

The use of foliage from trees and shrubs in ruminant animal nutrition has been focused by many researchers, due to the fact that these feed resources are locally available, perennial sources of feeds (Leng, 1997), rich in protein and particularly appropriate for small ruminants (Seng Sokerya and Rodriguez, 2001).

This review article therefore is based on feeding of browse plants containing tannins on the intestinal parasites in small ruminant animal by small holder farmers, as a control measure.

\section{Importance of browse tree/shrub in ruminant animal nutrition}

The potential of leaf meals from tropical trees and shrubs as feed is its ability to yield relatively higher levels of crude protein and minerals and lower crude fiber levels than tropical grasses is well recognized (D'Mello, 1992). Leaves from browse and fodder trees form a major part of livestock feed in tropical countries, (Mandal, 1997) and play an especially important role in improving dietary protein (Aregheore et al., 1998; Kaitho et al., 1998) as a supplementary feed.

ILCA studies in Nigeria established that the use of Leucaena and Gliricidia as supplementary feeds significantly increased the growth and survival rates of lamb. Statistical analyses of the data showed that each $100 \mathrm{~g}$ of browse DM consumed per day raises the productivity index by $1.41 \mathrm{~kg}$ lamb weaned/dam/year (Atta-Krah and Reynolds, 1989). Muinga et al. (1992) established that considerable increases in milk yield can occur in dairy cows fed on Napier grass (bana grass) when supplemented with Leucaena leucocephala leaf meal.

Nutritional implication of Condensed Tannins

Condensed tannins (CT) can complex with numerous types of molecules including proteins, polysaccharides, nucleic acids, and minerals (Haslem, 1989). Formation of the CT-protein complex is influenced by many factors, such as $\mathrm{pH}$, composition, and molecular weight of both the tannin and the proteins (Asquith and Butter, 1986).

High CT concentrations such as those in $L$. pedunculatus (63 to $106 \mathrm{~g}$ of CT/ $\mathrm{kg}$ of DM) substantially depressed feed intake, digestibility, and animal production in sheep (Barry and Duncan, 1984; Waghorn et al., 1994).

Moderate levels of CT (20 to $40 \mathrm{~g}$ of CT $/ \mathrm{kg}$ of $\mathrm{DM}$ ) bind to protein by hydrogen bonding at near neutral $\mathrm{pH}$ ( $\mathrm{pH} 6.0$ to 7.0) in the rumen to form CT-protein complexes, but dissociate and release bound protein at $\mathrm{pH}$ less than 3.5 in the abomasum (Barry et al., 2001). Thus, CT-containing plants can protect dietary protein against degradation in the rumen and increase amino acid supply to the abomasum and small intestine, resulting in a improved nutritional status of the animal. At similar CT concentrations ( 0.25 to $1.75 \mathrm{mg}$ of CT/ mg of total soluble plant protein), Lotus pedunculatus CT was more effective at protecting the plant protein from degradation by rumen microorganisms than Lotus corniculatus CT (Aerts et al., 1999). Therefore, a reduction of protein degradation in the rumen will increase the quantity of protein digested in the small intestine, potentially increasing animal production. 
Tannin potential in the control of Intestinal parasites

Condensed tannins may have direct effects on internal parasites themselves or may indirectly control the parasites by increasing the resistance and resilience of animals to gastro intestinal parasites infections through improved protein nutrition. Evidence in support of the direct affect of condensed tannin was provided by Molan et al. (2000), who demonstrated that the condensed tannin extracted from $L$. pedunculatus, L. corniculatus, $H$. coronarium, and $O$. viciifolia forages reduced the rate of larval development by $91 \%$, reduced the number of eggs hatching by $34 \%$, and decreased the mobility of larvae by $30 \%$.

Min et al. (2002b) showed a 57\% reduction in FEC and a $61 \%$ reduction in total fecal egg output in goats that consumed forage $L$. cuneata $(66 \times 104 \mathrm{eggs} / \mathrm{d})$ compared with control forage $(168 \times 104 \mathrm{eggs} / \mathrm{d})$. These results suggest that forage containing 5\% extractable CT may substantially reduce the contamination of pastures with infective larvae and result in reduced need for anthelmintic drenches.

Molan et al. (2000; 2002) have shown that CT extracted from several forages can disrupt the life cycle of nematodes by preventing their eggs from hatching and by preventing larval development to the infective stages.

Fecal egg count and parasite burdens at slaughter were considerably lower for lambs grazing $H$. coronarium (CTcontaining forage) than for lambs grazing M. sativa (Niezen et al., 1995; 1998a, b). Dewormed lambs grew at similar rates when grazing $H$. coronarium or $M$. sativa. However, nondewormed lambs grew much better on the $H$. coronarium, indicating a reduced need for anthelmintic drugs to control intestinal parasite in grazing lambs.
Also Niezen et al. (1995) that direct effects of condensed tannin on intestinal parasites may account for reduced fecal egg counts and nematode burdens in lambs that grazed Hedysarum coronarium compared to $M$. sativa in New Zealand.

Lin et al. (2003) also found a possible antiparasitic effect of cassava in naturally infected goats. When they offered foliage including cassava ad libitum for five months, FEC were lower than in goats fed grass in addition to rice bran and a molasses urea block only. Furthermore, when Dung et al. (2005) replaced concentrate with cassava hay at rates from 250 to $1000 \mathrm{~g} / \mathrm{kg}$ $\mathrm{DM}$, in a diet that contained guinea grass and dried cassava tuber slices, fecal egg count of naturally infected goats were gradually reduced with the increasing levels of cassava hay.

\section{Conclusion}

Apart from providing feed resource for the ruminant livestock, condensed tannincontaining forages have the potential to help control anthelmintic-resistant gastrointestinal parasites at various stages of their development. This reduces pasture contamination and ingestion of infective larvae and by itself might provide adequate control of gastrointestinal parasites. Also the use of tannin rich browse plants reduces cost of intestinal parasite control and the problems of drug resistance and improvement in the performance of ruminant animals.

\section{References:}

Aerts R. J., McNabb W.C., Molan A. Brand A., Peters J.S. and Barry T.N. 1999. Condensed tannins from Lotus corniculatus and Lotus pedunculatus affect the degradation of ribulose 1,5bisphosphate carboxylase (Rubisco) protein in the rumen differently. J. Sci. 
FoodAgric. 79:79-85.

Aregheore E. M., Makkar H.P.S. and Becker K. 1998. Feed value of some browse plants from the Central Zone of Delta State, Nigeria. Tropical Sci. 38, 97-104.

Asquith T. N. and Butter L.G. 1986. Interactions of condensed tannins with selected proteins. Phytochemistry 25, 1591-1593.

Atta-Krah 1989. Fodder trees and shrubs in tropical Africa: Importance, availability and patterns of utilization", Pages 118-138. Integration of livestock with crops in response to increasing population pressure on available resources, CTASeminar proceedings, Mauritius.

Barry T. N. and Duncan S.J. 1984. The role of condensed tannins in the nutritional value of Lotus pedunculatus for sheep. 1. Voluntary intake. Br. J. Nutr. 51, 493-504.

Barry T. N., McNeill D.M. and McNabb W.C. 2001. Plant secondary compounds; their impact on nutritive value and upon animal production. Pages 445-452 in Proc. XIX Int. Grass. Conf., Sao Paulo, Brazil.

Bhattacharya N. K (Editor) 1989. Goat rearing. Central Institute for Research on Goats. Mathura, Vijay Printing Press, India

Bourzat D. 1980. Paramètres zootechniques des espèces ovines et caprines de type mossi et de type peul. IEMVT, Paris, $11 \mathrm{p}$.

Chandrawathani P., Yussof N. and Waller P.J. 2004. Total anthelmintic failure to control nematode parasites of small ruminants on government breeding farms in Sabah, east Malaysia. Vet. Res. Communications 28, 479-89.

D'Mello J. P. F. 1992. Nutritional potentialities of fodder trees and shrubs as protein sources in Monogastric nutrition. Pages115-127 in: Legumes trees and other fodder, A. Speedy and P.L. Pugliese eds. Food and Agriculture Organization, Rome, Italy.

Dung N.T., Nguyen T.M. and Ledin I. 2005. Effect of replacing a commercial concentrate with cassava hay (Manihot esculenta Crantz) on the performance of growing goats. Anim. Feed Sci. Techno. 119, 271-81.

H a s l e m E . 1989 . P l a n t Polyphenols-Vegetable Tannins. Cambridge Univ. Press, U.K.

Hood G.M. 2004. Anthelmintic resistance in small ruminant parasites: Implications for smallholders in Southeast Asia. Pages51-61 in Worm control for small ruminants in tropical Asia. R.A. Sani, D.G. Gray and Baker, R.L. Eds. ACIAR Monograph, no. 113,

Kaitho R. J., Nsahlai I. V., Williams B. A., Umunna N.N., Tamminga S. and Van Bruchem J. 1998. Relationship between preference, rumen degradability, gas production and chemical composition of browses. Agroforest. Syst. 39, 129-144

Kimambo A. E., MacRae J.C., Walker A. Watt C.F. and Coop R.L. 1998. Effect of prolonged subclinical infection with Trichostrongylus colubriformis on the performance and nitrogen metabolism of growing lambs. Vet. Parasit. 28,191-203.

Leng R.A. 1997. Tree foliage in ruminant nutrition. FAO Animal Production and Health Paper No. 139, FAO, Rome, Italy.

Lin N.K., Preston T.R., Binh D.V. and Ly N.D. 2003. Effects of tree foliages compared with grasses on growth and intestinal nematode infestation in 
confined goats. Livestock Research for Rural Development, 15 (6). A va i 1 a ble from : http://www.cipav.org.co/lrrd/1rrd15/6/ lin156.htm

Mandal L. 1997. Nutritive value of tree leaves of some tropical species for goats. Small Rum. Res. 24:95-105.

Min B. R., Pomroy W., Hart S. and Sahlu T. 2002. The effect of forage condensed tannins on gastrointestinal parasite infection in grazing wether goats. J. Anim. Sci. 80(Suppl. 1), 31. (Abstr.)

Molan A. L., Waghorn G.C. and McNabb W.C. 2002. Effect of condensed tannins on egg hatching and 1 a r val deve 1 o p ment of Trichostrongylus colubrifomis in vitro. Vet. Rec. 19, 65-69.

Molan A. L., Waghorn G.C., Min B.R. and McNabb W.C. 2000. The effect of condensed tannins from seven herbages on Trichostrongylus colubriformis larval migration in vitro. Folia Parasitol. 47, 39-44.

Muinga R. W., Thorpe W. and Topps J. H. 1992. Voluntary food intake, live weight change and lactation performance of crossbred dairy cows given ad libitum Pennisetum purpureum (Napier grass var. Bana) supplemented with leucaena forage in the lowland semi-humid tropics. Anim. Prod.55.331-337.

Niezen J. H., Robertson G.C., Waghorn G.C. and Charleston W.A.G. 1998a. Production, fecal egg counts and worm burdens of ewe lambs which grazed six contrasting forages. Vet. Parasit. $80: 15-27$.

Niezen J. H., Waghorn G.C. and Charleston W.A.G. 1998 b. Establishment and fecundity of Ostertargia circumcincta and
Tricostrongylus colubriformis in lambs fed lotus (Lotus pedunculatus) or perennial ryegrass (Lolium perenne). Vet. Parasit. 78,13-21.

Niezen J. H., Waghorn T.S., Charleston W.A. and Waghorn G.C. 1995. Growth and gastrointestinal parasitism in lamb grazing one of seven herbages and dosed with larvae for six weeks. $J$. Agric. Sci. 125:281-289.

Njoya A., Awa D.N. and Chupamom J. 2005. The effects of a strategic supplementation and prophilaxis on the reproductive performance of primiparous Fulbe ewes in the semiarid zone of Cameroon. Small Rum. Res. 56(1-3), 21-29.

Pomroy W. E., Hart S.P. and Min B.R. 2002. Titration of efficacy of ivermectin and moxidectin against an ivermectin-resistant Haemonchus contortus derived from goats in the field. J. Anim. Sci. 80(Suppl. 2), 30. (Abstr.)

Prichard R. 1994. Anthelmintic resistance. Vet. Parasit. 54:259-268

Roy N.C., Bermingham E.N., Sutherland I.A. and McNabb W.C. 2003. Nematodes and nutrient portioning. Australian Journal of Experimental Agriculture 43, 1419-26.

Seng Sokerya and Rodriguez L. 2001. Foliage from cassava, Flemingia macrophylla and bananas compared with grasses as forage sources for goats: effects on growth rate and intestinal nematodes. Livestock Research for Rural Development. $13 \quad\left(\begin{array}{cc}2 & 2\end{array}\right)$ : http://www.cipav.org.co/lrrd//rrd13/2/ soke132.htm Accessed March 2010.

Shavulimo R. 1989. Endoparasites as a constraint to goat improvement in Kenya. African small ruminant research and development.Pages 382- 
390. Proceedings of a conference held at Bamenda, Cameroon 18-25 January 1989;

Sykes A.R. and Greer A.W. 2003. Effects of parasitism on the nutrient economy of sheep. Australian Journal of Experimental Agriculture 43, 1393-98.

Waghorn G. C., Shelton I.D., McNabb
W.C., McCutcheon S.N. 1994. Effects of condensed tannins in Lotus pedunculatus on its nutritive value for sheep. 2. Nitrogeneous aspects. $J$. Agric. Sci. 123:109-119.

Williamson G. and Payne W.J.A. 1978. An introduction to animal husbandry in the tropics. The English Language Book Society and Longmans, London.

Received: $20^{\text {th }}$ October, 2010 Accepted: $15^{\text {th }}$ Decem ber, 2013 